Heidi Julien

SUNY at Buffalo, Buffalo, New York, USA

Melissa Gross

Florida State University, Tallahassee, Florida, USA

Don Latham

Florida State University, Tallahassee, Florida, USA

\title{
INSTRUCTION FROM THE MARGINS: GIVING VOICE TO COMMUNITY COLLEGE LIBRARIANS (Paper)
}

\begin{abstract}
Résumé:
This study explores the experiences of community college librarians in the United States with instructional responsibility, as they negotiate professional guidelines that challenge their existing practices. Community college environments, students, and programs differ significantly from those typically explored in information literacy research. Thus, the study gives voice to a relatively marginalized set of librarians, many of whom struggle to implement instructional approaches perceived to be more suitable for university contexts.
\end{abstract}

\section{Introduction and Goal of the Study}

Community college librarians have been marginalized in scholarship focused on information literacy instruction in the academic library context; as Contrada (2019 states, "It is because of the uniqueness of community colleges that community college librarians often feel left out of major conversations surrounding information literacy at the college level” (p. 15). Community colleges differ significantly from universities, in terms of their broad missions, student bodies, programming, and staffing. Students studying at community colleges are typically older, employed, financially challenged, and juggling family demands to an extent not typical for university students (Dougherty, Lahr, \& Morest 2017; Rosenbaum, Ahearn, \& Rosenbaum 2016). Community colleges offer a wide range of programs, including academic and practical, and their students have a range of goals, including transfer to a university, apprenticeships, and moving directly into the workforce. In addition, community colleges are staffed with a significantly larger proportion of adjunct faculty than is the case in universities (Lederman, 2019). These differences, then, suggest that community college library services need to be tailored to their particular context.

One of the challenges facing community college librarians who provide information literacy instruction (ILI) is the current set of guidelines for academic librarians providing ILI, ACRL's Framework for Information Literacy for Higher Education (“Framework”) (2016), which replaces an approach based on skills development with a conceptual approach based on threshold concepts, knowledge practices, and dispositions. The ACRL now defines information literacy as "the set of integrated abilities encompassing the reflective discovery of information, the 
understanding of how information is produced and valued, and the use of information in creating new knowledge and participating ethically in communities of learning” (ACRL 2016, 3). ILI is expected to be infused throughout programs of study, and librarians are expected to collaborate with faculty and campus administration in realizing the goals of the Framework. Concerns about the perceived marginalization of community college libraries in the literature, and about the degree to which the Framework is appropriate for the community college setting, have motivated this study (Reed, 2015; Ludovico, 2017).

The study reported here is the third phase of a project funded by the Institute of Museum and Library Services in the U.S., which is exploring ILI in community colleges. The first phase surveyed community college librarians to explore their ILI and their perceptions of their students’ ILI needs (Julien, Latham, Gross, Moses, \& Warren, 2020); the second phase interviewed community college students about their perceptions of their ILI needs (Latham, Gross, Julien, Warren, \& Moses, submitted for publication); and, the third phase of the study, reported here, interviewed community college librarians about their ILI experiences, particularly with the Framework. The research question in this phase asks: What are community college librarians' experiences with the Framework, and what are their perceptions of their students' information literacy needs? This phase complements and extends the survey data gathered in phase one, asking similar questions about instructional practices and responses to the ACRL Framework (ACRL, 2016).

\section{Method}

Online semi-structured interviews with 30 librarians with instructional responsibilities in New York and Florida, two demographically diverse states with extensive community college systems, focused on participants' ILI experiences, particularly with the Framework. Ethics approval for the study was obtained from Florida State University. Participants were recruited using an invitation sent directly to all community college librarians in both states who have responsibility for ILI. Interviews lasted between 15 and 74 minutes. Interviews were audiorecorded and transcribed, and the transcripts are being analyzed qualitatively, using a grounded theory approach.

\section{Results and Discussion}

Results of the first phase of the study revealed that community college librarians' ILI has been influenced less by the Framework than is the case for their colleagues in universities. Survey respondents in phase one expressed concerns about the conceptual approach taken in the Framework, and about the degree to which the language that is used in that document is appropriate for the community college context (citation anonymized). Student interview respondents in phase two of the study indicated that their instructional experiences have been exclusively skills-based, rather than conceptual, but they appreciate the ILI they have received from community college librarians. The CAIS/ACSI presentation will present results from the third phase of the study, interviews with 30 community college librarians.

\section{Implications}


The value of this study lies in the potential for identifying opportunities for improving ILI in community colleges, based on a better understanding of librarians' attitudes and experiences of their instructional roles. Community college librarians with responsibility for ILI can be more fully supported in their work when their instructional landscapes and challenges are better understood. There are also implications for the preparation of pre-service librarians, whose learning should be informed by a current, in-depth understanding of ILI opportunities and challenges across instructional contexts. There is no assumption that these findings apply equally to the Canadian context, although there is no reason to expect otherwise, given the similarities between the U.S. and Canada in community colleges and in information literacy instruction practice (Julien, Latham, \& Gross, 2018; Polkinghorne \& Julien, 2019).

This proposal connects with the conference theme by focusing on the often-overlooked perspectives and experiences of librarians working in community colleges.

\section{Reference List:}

Association of College and Research Libraries. (2016). Framework for information literacy for higher education. Chicago, IL: American Library Association. Retrieved from http://www.ala.org/acrl/standards/ilframework

Contrada, C. (2019). Reference and information literacy in the community college library. Reference \& User Services Quarterly, 59(1), 12-16.

Dougherty, K. J., Lahr, H., \& Morest, V. S. (2017). Reforming the American community college: Promising changes and their challenges. CCRC Working Paper No. 98. Community College Research Center, Teachers College, Columbia University.

Julien, H., Gross, M., \& Latham, D. (2018). Survey of information literacy instructional practices in U.S. academic libraries. College \& Research Libraries 79(2): 179-199.

Julien, H., Latham, D., Gross, M., Moses, L., \& Warren, F. (2020). Information literacy practices and perceptions of community college librarians in Florida and New York. Communications in Information Literacy 14(2), 287-324. https://pdxscholar.library.pdx.edu/comminfolit/vol14/iss2/7/

Latham, D., Gross, M., Julien, H., Warren, F., \& Moses, L. (2021). Community college students' perceptions of their information literacy needs. College \& Research Libraries (submitted).

Lederman, D. (2019). The faculty shrinks, but tilts to full-time. Inside Higher Ed. November 27. https://www.insidehighered.com/news/2019/11/27/federal-data-show-proportioninstructors-who-work-full-time-rising

Ludovico, C. (2017). Seeing the world through adult eyes. College \& Research Libraries News, 78(5), 250.

Polkinghorne, S., \& Julien, H. (2019). Survey of information literacy instructional practices in Canadian academic libraries. Canadian Journal of Information and Library Science 42(1-2), 69-93.

Reed, K. L. (2015). Square peg in a round hole? The Framework for Information Literacy in the community college environment. Journal of library administration, 55(3), 235-248.

Rosenbaum, J. E., Ahearn, C., \& Rosenbaum, J. (2016). The community college option. Educational Leadership, 73(6), 48-53. 